\title{
Selective COX-2 inhibitor reduces bone healing in bone defects
}

\section{Inibidor seletivo de COX-2 reduz reparo em defeitos ósseos}

\author{
Bruno César de Vasconcelos Gurgel* \\ Fernanda Vieira Ribeiro** \\ Marco Antônio Dias da Silva*** \\ Francisco Humberto Nociti Júnior**** \\ Antonio Wilson Sallum $* * * *$ \\ Enilson Antônio Sallum***** \\ Sérgio de Toledo****** \\ Márcio Zaffalon Casati*******
}

\begin{abstract}
Anti-inflammatory agents have been reported to regulate bone healing. The aim of this study was to investigate the effect of a selective cyclooxygenase-2 inhibitor (meloxicam) on bone healing in calvarial defects in rats. Thirty-six adult male Wistar rats were included. After anesthesia, a linear incision was made through the skin of the scalp, a full-thickness flap was reflected and a $4 \mathrm{~mm}$ round defect was made with a trephine drill. The animals were randomly assigned to one of the following 4 treatment groups ( 9 animals each), including daily subcutaneous injections: A: saline solution for 15 days; B: saline solution for 45 days; C: $3 \mathrm{mg} / \mathrm{kg}$ of meloxicam for 15 days and D: $3 \mathrm{mg} / \mathrm{kg}$ of meloxicam for 45 days. The animals were sacrificed and the specimens, routinely processed. The bone filling was histometrically measured and statistical analysis, performed. Intergroup comparisons demonstrated that the meloxicam groups presented a significant reduction in bone healing when compared to their respective controls (group A, $44.5 \pm 5.75 \%$, against group C, $57.5 \pm 7.25 \%, \mathrm{p}<0.05$; group B, $40.25 \pm 13.75 \%$, against group $\mathrm{D}, 52.25 \pm 17.25 \%$ ). Within the limits of the present study, it can be concluded that selective cyclooxygenase-2 inhibitors may reduce bone healing in calvarial defects in rats after continuous administration.
\end{abstract}

DESCRIPTORS: Anti-inflammatory agents, non-steroidal; Cyclooxygenase inhibitors; Wound healing; Rats.

\begin{abstract}
RESUMO: Agentes antiinflamatórios têm sido descritos como reguladores do reparo ósseo. O objetivo deste estudo foi investigar o efeito de um inibidor seletivo da cicloxigenase-2 (meloxicam) no reparo ósseo em defeitos de calvárias de ratos. Trinta e seis ratos machos Wistar foram incluídos no estudo. Após anestesia, incisão linear e rebatimento de retalho de espessura total, um defeito de $4 \mathrm{~mm}$ de diâmetro foi criado na calvária dos animais com broca trefina. Os mesmos foram aleatoriamente distribuídos em um dos 4 grupos de tratamento (9 animais por grupo), recebendo injeções subcutâneas diárias de: A: soro fisiológico por 15 dias; B: soro fisiológico por 45 dias; C: $3 \mathrm{mg} / \mathrm{kg}$ de meloxicam por 15 dias; D: $3 \mathrm{mg} / \mathrm{kg}$ de meloxicam por 45 dias. Os animais foram sacrificados e os espécimes rotineiramente processados. Medidas do preenchimento ósseo foram histometricamente realizadas e analisadas estatisticamente. Comparações intergrupos demonstraram que os grupos com meloxicam apresentaram uma redução significativa no reparo ósseo quando comparados com os respectivos grupos-controle (grupo A, $44,5 \pm 5,75 \%$, contra grupo C, $57,5 \pm 7,25 \%$, p < 0,05; grupo B, 40,25 $\pm 13,75 \%$, contra grupo D, $52,25 \pm 17,25 \%$ ). Dentro dos limites do presente estudo, pode ser concluído que os inibidores seletivos da cicloxigenase-2 podem reduzir o reparo ósseo em defeitos em calvárias de ratos após sua administração contínua.
\end{abstract}

DESCRITORES: Antiinflamatórios não esteróides; Inibidores de ciclooxigenase; Cicatrização de feridas; Ratos.

\section{INTRODUCTION}

The effect of anti-inflammatory drugs on bone healing has been evaluated in several studies ${ }^{1,3,11}$. Non-steroidal anti-inflammatory drugs (NSAIDS) interfere with aracdonic acid metabolism by blocking prostaglandin synthesis through cyclooxygen- ase pathway inhibition, which has a fundamental role in bone healing ${ }^{22,24}$.

Selective COX-2 inhibitors have emerged with the objective of reducing stomach and renal toxicity. Additionally, they can also promote effects on

\footnotetext{
* PhD Student, Department of Prosthodontics and Periodontics, Division of Periodontics; **Graduate Student, Department of Prosthodontics and Periodontics, Division of Periodontics; ***PhD Student, Department of Histology, Division of Morphology; $* * * *$ Professors, Department of Prosthodontics and Periodontics, Division of Periodontics; *****Professor and Chairman, Department of Prosthodontics and Periodontics, Division of Periodontics; *****Visiting Professor, Department of Prosthodontics and Periodontics, Division of Periodontics; ${ }^{* * * * * *}$ Assistant Professor, Department of Prosthodontics and Periodontics, Division of Periodontics - School of Dentistry at Piracicaba, State University of Campinas.
} 
Gurgel BCV, Ribeiro FV, Silva MAD, Nociti Júnior FH, Sallum AW, Sallum EA, Toledo S, Casati MZ. Selective COX-2 inhibitor reduces bone healing in bone defects. Braz Oral Res 2005;19(4):312-6.

bone healing inhibiting prostaglandins ${ }^{23}$. It has been shown that the COX-2 enzyme participates in early phases of osteogenesis and that it is more related to osteoblast maturation in later stage ${ }^{20}$. COX-2 inhibitors reduce the osteoblastogenesis process and alter genes activities responsible for osteoblastic differentiation ${ }^{19,23}$.

In order to clarify the role of NSAIDS on bone healing after surgical procedures, the purpose of the present study was to evaluate the influence of meloxicam, a selective COX-2 inhibitor, on bone healing in calvarial defects in rats.

\section{MATERIALS AND METHODS Animals}

Thirty-six male Wistar rats (250-350 g) were included in the study. The animals were kept in plastic cages with access to food and water ad libitum. Prior to surgical creation of the defects, all animals were allowed to acclimatize to the laboratory environment for a period of 7 days. The protocol was approved by the State University of Campinas Institutional Animal Care and Use Committee.

\section{Experimental design}

General anesthesia was obtained by intramuscular administration of ketamine $(0.5 \mathrm{ml} / \mathrm{kg})$ (Dopalen $^{\circledR}$, Agribrands Brasil Ltda., Paulinia, SP, Brazil). After cranial dorsal tricotomiae, the surgical site was scrubbed with iodine (Geyer Medicamentos S.A., Porto Alegre, RS, Brazil) and a $15 \mathrm{~mm}$ mid-sagittal linear incision was made through the skin of the scalp. A full-thickness flap, including periosteum, was then reflected, exposing the calvarial bone. After dissection and bone exposure, a standardized, circular defect with $4 \mathrm{~mm}$ in diameter was made in one side of the parietal bone with the use of a trephine drill ( $3 \mathrm{i}^{\circledR}$ Implants Innovations do Brasil Ltda., São Paulo, SP, Brazil) and abundant irrigation with sterile saline solution (Fresenius Kabi Brasil Ltda., Campinas, SP, Brazil), exposing the dura mater membrane. The soft tissues and periosteum were then repositioned for total coverage and sutured with 4.0 mono-nylon suture (Shalon ${ }^{\circledR}$, B.A. da B. Vista, S.L.M. Belos, GO, Brazil). The animals were then randomly assigned to one of 4 groups $(9$ animals (group) that were subjected to daily subcutaneous injections. Groups A and B received continuous administration of $1 \mathrm{ml} / \mathrm{kg}$ of saline solution for 15 and 45 days, respectively; and groups $\mathrm{C}$ and $D$ received continuous administration of $3 \mathrm{mg} / \mathrm{kg}$ of meloxicam (Movatec ${ }^{\circledR}$ - Boehringer Ingelheim do
Brasil Química e Farmacêutica Ltda., Itapecerica da Serra, SP, Brazil) for 15 and 45 days, respectively.

The animals were sacrificed by deep anesthesia, and the calvarial bones, including the surgical sites, were removed and fixed in 4\% neutral formalin (Dinâmica ${ }^{\circledR}$ Reagentes Analíticos, São Paulo, SP, Brazil) for 48 hours. The specimens were demineralized in a solution with equal parts of $50 \%$ formic acid (Dinâmica ${ }^{\circledR}$ Reagentes Analíticos, São Paulo, SP, Brazil) and $20 \%$ sodium citrate (Chemco Indústria e Comércio Ltda., Campinas, SP, Brazil) for 40 days. Paraffin semi-serial sections $(6 \mu \mathrm{m})$ were obtained in an anteroposterior direction and stained with hematoxilin and eosin (Dinâmica ${ }^{\circledR}$ Reagentes Analíticos, São Paulo, SP, Brazil). Twenty sections were uniformly selected from the beginning to the end of the defect and analyzed with a light microscope (Zeiss, Jena, Germany) under a 2.5 X magnification. Using an image analysis system (Image-Pro ${ }^{\circledR}$; Media Cybernetics, Silver Spring, MD, USA), linear measurements of the healing remaining defect were calculated from one side to the other side of the bone by the same examiner. A blind examiner was trained and calibrated in performing the measurements.

Measurements of the twenty sections were averaged to allow intra- and intergroup analysis related to time. Comparisons between groups were made by Bifactorial Variance Analysis with a significance level of $5 \%$.

\section{RESULTS \\ Histologic analysis}

Two weeks postsurgically, the presence of a thin connective tissue membrane was observed over the defect sites in both control and treated samples. The connective tissue layer of test animals presented an advanced process of angiogenesis, and a decreased number of hemorrhagic and inflammatory sites, when compared to the samples of the control animals. However, new bone formation, originated from the margins and/or as bone isles throughout the defect, was greater in the control groups than in the test groups $(p<0.05)$. In addition, cubical or cylindrical osteoblasts were observed in the control groups (Figure 1) while in the test group, osteoblasts were squamous (surface or bone lining cells) (Figure 2).

Forty five days postsurgically, both groups exhibited an enhancement in bone formation. The connective tissue layer appeared mature, characterized by large and organized collagen (type I) fibers and by the reduction of hemorrhagic and inflammatory cell infiltration throughout the defect. Defect margins tended to be connected by newly 


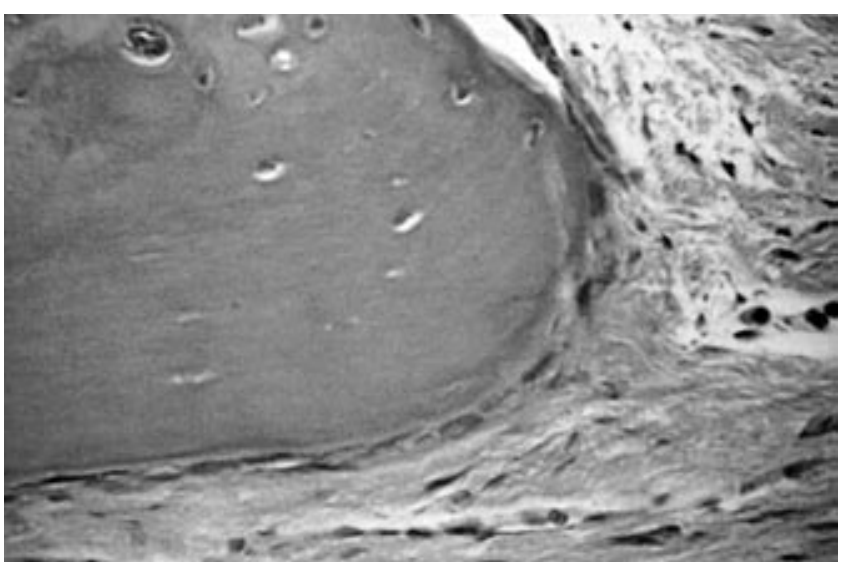

FIGURE 1 - In control groups, osteoblasts surfacing the bone were cubical or cylindrical. Magnification $50 \mathrm{X}$. H. E.

TABLE 1 - Mean percentages and standard deviations of linear measurements from the remaining defect of the control and test groups at 15 and 45 days.

\begin{tabular}{c|c|c}
\hline \hline Period (days) & Control Group & \multicolumn{2}{c}{ Test Group } \\
\hline $15(\mathrm{~A}-\mathrm{C})$ & $44.5 \pm 5.75 \% \mathrm{a}$ & $57.5 \pm 7.25 \% \mathrm{~b}$ \\
\hline $45(\mathrm{~B}-\mathrm{D})$ & $40.25 \pm 13.75 \% \mathrm{a}$ & $52.25 \pm 17.25 \% \mathrm{~b}$ \\
\hline \hline
\end{tabular}

Means followed by different letters differ statistically by Bifactorial Variance Analysis $(\mathrm{p}<0.05)$.

formed bone in the control groups, whereas the test groups presented a pattern similar to that of the 15 days observations, marked by squamous osteoblasts originating small amounts of osteoid matrix and reduced bone formation.

\section{Histomorphometric analysis}

Data from linear measurements of remaining osseous defect were subtracted from the original defect $(4 \mathrm{~mm})$ and mean percentages and standard deviations were also subtracted from the original size defect (Table 1) (Figura 3).

Statistically significant differences $(p<0.05)$ were observed between group $\mathrm{A}$ and $\mathrm{C}$ and between $B$ and D. However, no significant difference was observed between experimental periods (A to B and $\mathrm{C}$ to $\mathrm{D})$.

\section{DISCUSSION}

The present study demonstrates, histologically, that COX-2 inhibitors may significantly decrease the bone healing in calvarial defects in rats. This is in accordance with other studies that have suggested that NSAIDS also inhibit bone re-

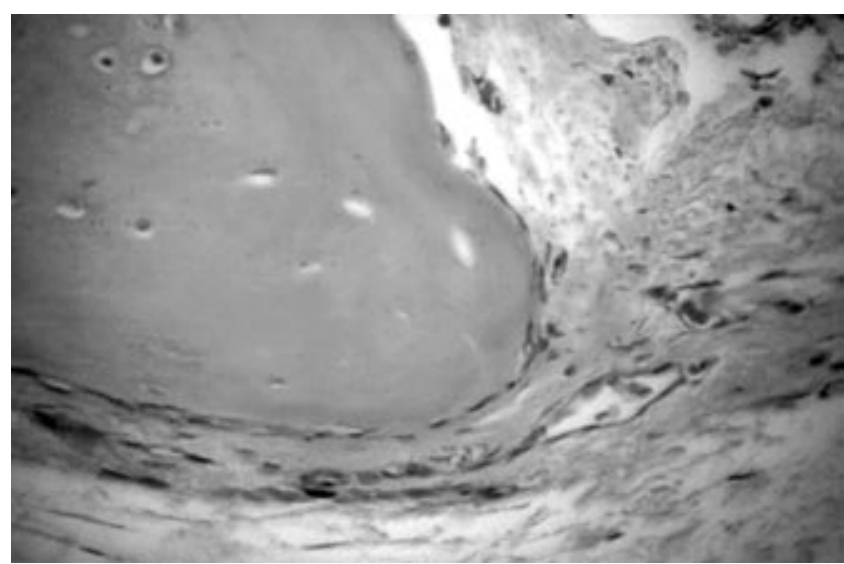

FIGURE 2 - In the test groups, osteoblasts were squamous (bone lining cells). Magnification 50 X. H. E.

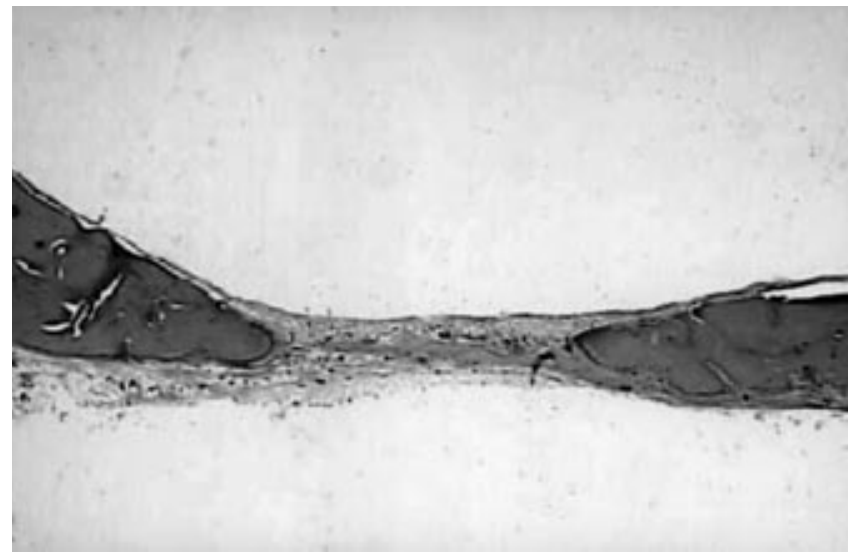

FIGURE 3 - Healing remaining defect between bone margins. Original magnification 2.5 X. H. E.

pair and bone formation ${ }^{12,21}$. This fact could be explained by prostaglandin synthesis inhibition, due to the blockade of cyclooxygenase, which has an important role in osteogenesis and bone healing, such as endochondral and intramembranous ossification $^{21,23}$.

Sato et al. ${ }^{20}$ (1997) showed that COX-2 and COX-1 have a fundamental role in early phases of osteogenesis. In addition, COX-2, in later stages, is more related to osteoblast maturation. Zhang et al. ${ }^{23}$ (2002) demonstrated that COX-2 regulates genes, such as cbfa 1 and osterix, which are required for osteoblast differentiation and bone formation. In this process, COX-1 does not have a critical role. Decreases in the expression of these genes may contribute to incomplete bone repair ${ }^{19}$, as observed in the present study. Therefore, since COX-2 regulates genes activities in osteoblastic differentiation, a reduction in the osteoblastogenesis 
Gurgel BCV, Ribeiro FV, Silva MAD, Nociti Júnior FH, Sallum AW, Sallum EA, Toledo S, Casati MZ. Selective COX-2 inhibitor reduces bone healing in bone defects. Braz Oral Res 2005;19(4):312-6.

process could be the main hypothesis to explain the remaining bone defects in the test groups observed in the present study.

Additionally, studies have shown that prostaglandins may increase fracture repair rates in experimental models, improving bone healing ${ }^{14}$ and also stimulating bone formation ${ }^{22,24}$. Zhang et ll. $^{23}(2002)$ has suggested that prostaglandins also participate in osteoblast recruitment and differentiation, and induce cbfa- 1 and osterix gene expression.

Previous studies have shown that COX-2 specific inhibitors may not have any effect on fracture healing in animal models ${ }^{5}$ and do not inhibit bone fusion following spinal arthrodesis ${ }^{16}$. On the other hand, studies also demonstrate that COX-2 inhibitors can present radiographic, histological, morphological, and biomechanical evidence of delayed fracture healing at four weeks ${ }^{12,21}$, even when administered before injury ${ }^{11,21}$.

As observed in the present study, the amount of bridging bone formation is reduced in the test groups $(\mathrm{p}<0.05)$, as compared to the control group, at 2 weeks. Although intragroup analysis did not show any significant difference in bone healing, a numerical difference could be observed favoring the latter control group.

In this study, the animals were treated for 15 or 45 days. Although studies have suggested that bone healing is increased during the first 15 days ${ }^{7,8}$, the present study investigated if a longer period (45 days) of bone repair could reduce the remaining calvarial defect more than 15 days, even in the control group.

The apparent stabilization of the healing process observed in the present study at 45 days postoperatively could be the result of using a critical size defect. The regenerative capacity of the bone tissue can be limited by the size of the defect, where large bone defects cannot regenerate spontaneously ${ }^{6}$. The critical size defect depends on animal species, age, size and place ${ }^{4}$. In calvaria of rats, this size can vary from $2 \mathrm{~mm}^{18}$ to $8 \mathrm{~mm}^{15}$. In the present study, a defect of $4 \mathrm{~mm}$ was not able to regenerate spontaneously, as shown in the latter control group.

Probably, the apparent high quantity of prostaglandins encountered in the early phase of healing, as observed in previous studies ${ }^{7,23}$, might justify the results of the present study, where differences in defect closure were not noticed between 15 and 45 days. This observation suggests that the high peak of osteogenesis activity may occur during the first 15 days. Dekel et al. ${ }^{7}$ (1981) showed that high prostaglandin levels (PGE and PGF) were increased between the $3^{\text {rd }}$ and $14^{\text {th }}$ days of repair in fractures of rat tibiae. According to the same authors, the mRNA expression of COX-2 was also higher during the first 14 days, demonstrating the role of COX and its metabolites during the early phases of healing. Gerstenfeld et al. ${ }^{9}$ (2003) also showed that COX-1 mRNA levels were constant during the first 21 days, while COX-2 mRNA levels presented peaks of elevation during the first 14 days of healing, and returned to basal levels after 21 days. These findings indicate that in the first two weeks of bone repair, the osteogenic activity is more intense because of the high rate of COX-2 transcription and, consequently, high levels of prostaglandins found in this period, since these metabolites stimulate bone formation ${ }^{22,24}$. These findings are in accordance with those of the present study, where increased bone healing was observed at 15 days compared to 45 days in non-treated groups, even without significant differences ( $p>0.05)$.

The histological analysis showed that, during the early phases, the control group presented cuboidal and cylindrical osteoblasts, characterizing a high activity of osteoid production (non calcified matrix). These findings could not be found in treated groups, where most of the osteoblasts were squamous, which demonstrates lower synthesis of osseous matrix. According to Marks et al. ${ }^{17}$ (1996), actively secreting mature osteoblasts are, histologically, cuboidal or tall cells. When they start to secrete bone, the secretion is polarized towards the bone surface. This could be explained by the role of both COX-1 and COX-2 enzymes during the early phases of osteogenesis ${ }^{20}$. In addition, COX-2, selectively inhibited by meloxicam, may also be associated with osteoblast maturation in later stages, which explains the morphological distinction and, consequently, the difference in activity observed in the osteoblasts on new bone surface (bone lining cells), when compared to the control group. This histological evidence, associated with the lack of hemorrhagic features, few inflammatory cells and normal tissue vascularization, characterize advanced bone and tissue healing processes ${ }^{2}$.

Ho et al. ${ }^{13}$ (1995) demonstrated that NSAIDS effects are dose-dependent and that, after withdrawal, their effects may be reverted ${ }^{1}$. Apparently, the use of NSAIDS seems to delay the healing process and their use should be avoided immediately postoperatively or should only be used during a short-term administration ${ }^{8}$, because early events in bone formation may be modulated by arachidonic acid metabolites ${ }^{25}$. However, further analy- 
Gurgel BCV, Ribeiro FV, Silva MAD, Nociti Júnior FH, Sallum AW, Sallum EA, Toledo S, Casati MZ. Selective COX-2 inhibitor reduces bone healing in bone defects. Braz Oral Res 2005;19(4):312-6.

ses in animal models and humans are required to clarify the mechanisms of the effect of nonsteroidal anti-inflammatory drugs such as COX-2 inhibitors, as well as the role of prostaglandins and cyclooxygenases in bone healing. As clinical studies are limited, as are retrospectives ${ }^{3,10}$, additional information about dosage and time of administration also need investigation in the future due to concerns emerging in the literature.

\section{CONCLUSION}

Within the limits of the present study, it can be concluded that meloxicam, a selective cyclo-

\section{REFERENCES}

1. Altman RD, Latta LL, Keer R, Renfree K, Hornicek FJ, Banovac K. Effect of nonsteroidal antiinflammatory drugs on fracture healing: a laboratory study in rats. J Orthop Trauma 1995;9(5):392-400.

2. Applegate EJ. The Anatomy and Physiology Learning System: Textbook. W.B. Philadelphia: Saunders Company; 1995.

3. Bichara J, Greenwell H, Drisko C, Wittwer JW, Vest TM, Yancey $\mathrm{J}$ et al. The effect of postsurgical Naproxen and a bioabsorbable membrane on osseous healing in intrabony defects. J Periodontol 1999;70(8):869-77.

4. Bosch C, Melsen B, Vargervik K. Importance of the Critical-Size bone defect in testing bone regenerating material. J Craniofac Surg 1998;9(4):310-6.

5. Brown KM, Saunders MM, Kirsch T, Donahue HJ, Reid JS. Effect of COX-2-specific inhibition on fracture-healing in the rat femur. J Bone Joint Surg Am 2004;86-A(1):116-23.

6. Cormack DH. Ham - Histologia. $9^{\mathrm{a}}$ ed. Rio de Janeiro: Guanabara Koogan; 1991.

7. Dekel S, Lenthall G, Francis MJ. Release of prostaglandins from bone and muscle after tibiae fracture. An experimental study in rabbits. J Bone Joint Surg Br 1981;63-B(2):185-9.

8. Gerstenfeld LC, Einhorn TA. COX inhibitors and their effects on bone healing. Expert Opin Drug Saf 2004;3(2):131-6.

9. Gerstenfeld LC, Thiede M, Seibert K, Mielke C, Phippard D, Svagr B et al. Differential inhibition of fracture healing by non-selective and cyclooxygenase- 2 selective non-steroidal anti-inflammatory drugs. J Orthop Res 2003;21(4):670-5.

10. Giannoudis PV, Macdonald D, Matthews SJ, Smith RM, Furlong J, De Bôer P. Nonunion of the femoral diaphysis. The influence of reaming and non-steroidal anti-inflammatory drugs. J Bone Joint Surg Br 2000;83(2):308.

11. Giordano V, Giordano M, Knackfuss IG, Apfel MI, Gomes RD. Effect of tenoxicam on fracture healing in rat tibiae. Injury 2003;34(2):85-94.

12. Goodman S, Ma T, Trindade M, Ikenoue T, Matsuura $\mathrm{I}$, Wong $\mathrm{N}$ et al. COX-2 selective NSAID decreases bone ingrowth in vivo. J Orthop Res 2002;20(6):1164-9.

13. Ho ML, Chang JK, Wang GJ. Antiinflammatory drug effects on bone repair and remodeling in rabbits. Clin Orthop Relat Res 1995;(313):270-8.

14. Keller J. Effects of indomethacin and local prostaglandin E2 on fracture healing in rabbits. Dan Med Bull 1996;43(4):317-29. oxygenase- 2 inhibitor, may reduce bone healing in calvarial defects in rats after continuous administration.

\section{ACKNOWLEDGMENTS}

This study was supported by Fundação de Amparo à Pesquisa do Estado de São Paulo - FAPESP, process 02/13416-6. We would also like to thank the histological technician, Mariana Piovezzan Fuggolin, who contributed to this study, and Gláucia Maria Bovi Ambrosano for the statistical analysis support.

15. Kleinschmidt JC. The critical size defects as an experimental model to test bone repair materials. J Craniofac Surg 1990;1(1):60-8.

16. Long J, Lewis S, Kuklo T, Zhu Y, Riew KD. The effect of cyclooxygenase-2 inhibitors on spinal fusion [abstract]. J Bone Joint Surg Am 2002;84:1763-8.

17. Marks SC Jr, Cielinski MJ, Sundquist KT. Bone surface morphology reflects local skeletal metabolism. Microsc Res Tech 1996;33(2):121-7.

18. Mulliken JB, Glowacki J. Induced osteogenesis for repair and construction in the craniofacial region. Plast Reconstr Surg 1980;65(5):553-60.

19. Nakashima K, Zhou X, Kunkel G, Zhang Z, Deng $\mathrm{JM}$, Behringer RR et al. The novel zinc finger-containing transcription factor osterix is required for osteoblast differentiation and bone formation. Cell 2002;108:17-29.

20. Sato Y, Arai N, Negishi A, Ohya K. Expression of cyclooxygenase genes and involvement of endogenous prostaglandin during osteogenesis in the rat tibial bone marrow cavity. J Med Dent Sci 1997;44(4):81-92.

21. Simon AM, Manigrasso MB, O' Connor JP. Cyclooxygenase 2 function is essential for bone fracture healing. $J$ Bone Miner Res 2002;17(6):977-8.

22. Suponitzky I, Weinreb M. Differential effects of systemic prostaglandin E2 on bone mass in rat long bones and calvariae. J Endocrinol 1998;156(1):51-7.

23. Zhang X, Schqarz EM, Young DA, Puzas JE, Rosier RN, O'Keefe RJ. Cyclooxygenase-2 regulates mesenchymal cell differentiation into the osteoblast lineage and is critically involved in bone repair. J Clin Invest 2002;110(8):1211.

24. Weinreb M, Suponitzky I, Keila S. Systemic administration of an anabolic dose of PGE2 in young rats increases the osteogenic capacity of bone marrow. Bone 1997;20(6):521-6.

25. Yazdi M, Cheung DT, Cobble S, Nimni ME, Schonfeld $\mathrm{SE}$. Effects of non-steroidal anti-inflammatory drugs on demineralized bone-induced bone formation. J Periodontal Res 1992;27(1):28-33.

Received for publication on Mar 07, 2005

Sent for alterations on Sep 23, 2005 Accepted for publication on Nov 21, 2005 